L. I. Solonenko ${ }^{1}$, Cand. Sc. (Tech.), orcid.org/0000-0003-2092-8044, O.P. Bilyi², orcid.org/0000-0003-1234-5404, S. I. Repiakh ${ }^{2}$, Dr. Sc. (Tech.), orcid.org/0000-0003-0203-4135, T.V.Kimstach ${ }^{2}$, orcid.org/0000-0002-8993-201X, K. I. Uzlov' ${ }^{2}$, Dr. Sc. (Tech.), Prof., orcid.org/0000-0003-0744-9890
1 - Odessa National Polytechnic University, Odessa, Ukraine 2 - National Metallurgical Academy of Ukraine, Dnipro, Ukraine, e-mail: 123rs@ua.fm

\title{
HEATING RATE OF GRANULAR INORGANIC MATERIALS BY MICROWAVE RADIATION
}

Purpose. Determining heating rate of granular materials of inorganic origin used for manufacturing foundry molds and rods in the field of ultra-high frequency radiation, dependence of the heating rate of materials on the magnitude of their relative dielectric permeability, as well as establishing the influence of the chemical composition and structure of inorganic materials on their relative dielectric permeability.

Methodology. Investigation was carried out on test material samples weighing 200 grams which were heated by microwave radiation with frequency of $2.45 \mathrm{GHz}$ at nominal magnetron power of $700 \mathrm{~W}$. Among the tested materials are: silicate block (soda), rutile, normal electro-corundum, zircon concentrate, distene-sillimanite concentrate, chamotte, quartz sand, sodium chloride, $\beta$-gypsum (G4, closed), $\alpha$-gypsum (G22, closed).

Findings. According to the results of changing the initial temperature of samples, the heating rate of granular materials of inorganic origin and values of their relative dielectric permeability $(\varepsilon)$ were calculated. It has been found that investigated the heating rate of industrial-grade materials is in the range from 12 (for closed gypsum grade $\mathrm{G} 22$ ) to $122{ }^{\circ} \mathrm{C} / \mathrm{min}$ (for silicate block).

Originality. Values of dielectric permeability indicators of solid granular materials-insulators of industrial purity with a value of $\varepsilon \leq 17$ have been established for the first time. It has been determined that their heating rate is directly proportional to $\varepsilon$ value. Moreover, these materials' dielectric permeability depends solely on their chemical composition and can be calculated according to the additivity rule of elementary chemical components included in their composition

Practical value. Based on the obtained data, materials appropriated for manufacturing casting model-core equipment, as well as casting molding and core mixtures working, dried and structured in the field of microwave radiation have been recommended. Using such materials will reduce energy consumption of casting parts production and increase its environmental safety.

Keywords: dielectric permeability, ultrahigh frequency radiation, granular material, heating rate, foundry mold, core

Introduction. Determination of electrical properties of dielectrics is one of the tasks of modern fundamental science, which is of great theoretical and practical importance. Electrical properties, including relative dielectric permeability (e), are determined by a variety of methods (resonance methods, loop detuning, coaxial, balanced, waveguide, short circuit, and others). Wide variety of these methods is conditioned by both accuracy and conditions of measurements performance, as well as formulation of the tasks to be solved, size specific, shape and structure of examined objects, and others.

With regard to disposable non-metallic foundry molds and cores production, as well as model-core equipment, one of the most important indicators of technologies, in which microwave radiation has been used for heating, is their granular material heating rate. Currently, in relation to natural origin domestic granular materials of technical purity, such data are absent or have fragmented character. Hence, work aimed at determining the heating rate, as well as at establishing the relationship between the heating rate of granular materials of natural and artificial origin of technical purity and their electrical parameters, is relevant.

Literature review. At the present time, ultrahigh frequency (UHF) radiation is used in a wide variety of technologies. In particular, it is applied for disinfection of wastewater, vulcanization of rubber, production of thermally expanding graphite, products from plastics and resins, extraction of ore materials, as well as in medicine, food and woodworking industry [1], in forest [2] and chemical industry [3], in agriculture [4], building [5], foundry [6] and other industrial branches.

(C) Solonenko L. I., Bilyi O.P., Repiakh S. I., Kimstach T. V., Uzlov K. I., 2020
In foundry manufacturing UHF radiation is used to a limited extent, mainly for molding and core materials, molds and cores drying, model composition smelting from ceramic shell molds. The limited use of UHF radiation in foundry technology is conditioned by its application peculiarities. Particularly, the types of tooling most used in foundries include models, model plates, flasks and core boxes. As a rule, wood, cast iron, steel, aluminum alloys, plastics, fiberglass, epoxides resins are used for their manufacturing [7, 8]. Materials suitable for conventional molding methods are not always suitable for use in UHF radiation heating applications. In particular, plastic masses and resins emit toxic substances and cancerogens when heated [9], metal accessories, fasteners and parts heat up quickly and, reflecting electromagnetic waves, lead to electric arc sparking appearance in UHF furnace working chamber [10], wooden equipment - charring and deforming. In this regard, among the materials for model-and-flask equipment, taking into account its heating in a UHF furnace, for example, the corresponding dielectric material slowly heating up in UHF radiation can be used.

The issues of dielectric materials heating were dealt with by many scientists and researchers [11, 12]. Nevertheless, methodology for determining the heating rate, adopted in some of such studies, involving the water tank installation in addition to the test material in UHF furnace working space [12], casts doubt on the adequacy of the obtained results. In addition, the heating rate of bulk granular materials of industrial purity, most often used for the production of foundry molds and cores, has not been determined.

Purpose of the study is to determine the heating rate of granular materials, used in foundry molds and cores manufacturing processes in UHF field, its dependence on relative di- 
electric permeability, to establish the degree of influence of chemical composition and structure of inorganic materials on relative dielectric permeability.

Methods and materials. To determine the rate of increase in materials' temperature during their heating by a UHF radiation device, schematically shown in Fig. 1.

According to the scheme in Fig. 1, the device is a container made of foam with an apparent density of $22 \mathrm{~kg} / \mathrm{m}^{3}$. Dimensions of the working cavity of a foam container are $\varnothing 40 \times$ $\times 70 \mathrm{~mm}$. In upper part of the container, its working cavity is closed with a foam cover.

To control the UHF furnace operability, before starting the next series of material tests, magnitude of the change in temperature of distilled water sample weighing $180 \pm 1 \mathrm{~g}$, heated in a cardboard cup, was determined. Any material test result was taken as true if, during preliminary control heating in the UHF furnace, water sample temperature increased by $38.3-38.7^{\circ} \mathrm{C}$ in $60 \mathrm{~s}$, and voltage in power supply of the UHF equipment during material testing was $220 \pm 3 \mathrm{~V}$.

During the experiment, 5 weighed samples of each test granular material were prepared. The weight of test portions was $180-220 \mathrm{~g}$ due to apparent density of the test material and volume of the working space of the used foam container-thermostat. Measurement of the initial temperature of the material samples was carried out 10-15 min after test material placing in the container thermostat. To measure the temperature with an accuracy of $0.1^{\circ} \mathrm{C}, \mathrm{NiCr}-\mathrm{CuNi}$, a thermocouple with working junction diameter of $0.2-0.3 \mathrm{~mm}$ was used. After measuring the temperature, the thermocouple was removed from the thermostat container, the working cavity was closed with a foam cover and thermostat container was installed in the rotation center of UHF furnace table.

In all the experiments, the duration of material processing in UHF furnace with frequency of $2.45 \mathrm{GHz}$ at nominal magnetron power of $P_{M}=700 \mathrm{~W}$ was $60 \mathrm{~s}$. At the end of the treatment the container was removed from UHF furnace and its contents were mixed by shaking from three to five times with simultaneous rotating on $180{ }^{\circ} \mathrm{C}$ in a vertical plane. After mixing, $\mathrm{NiCr}-\mathrm{CuNi}$ thermocouple was put into the working cavity of the container to certain depth and repeated temperature measurement was performed. The number of the same measurement repetitions for one sample was 2 .

The following materials were selected for testing in this work:

- as ecologically and sanitary-hygienically safe binding material for disposable mixtures of foundry molds and cores - silicate block (soda), corresponding to GOST 917-41;

- as refractory granular materials for disposable foundry molds and cores - rutile (GOST 22938-78), normal aluminum-oxide (GOST 28818-90), zircon concentrate (GOST

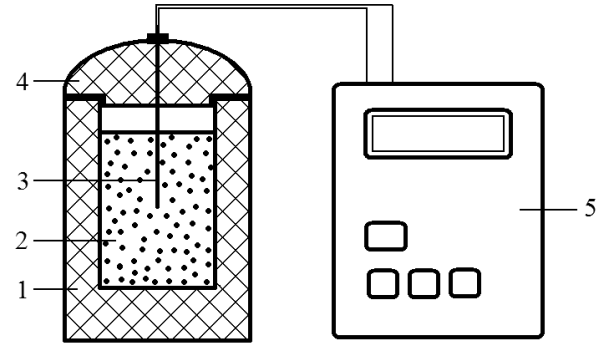

Fig. 1. Scheme of device for determining the temperature change in bulk materials during their heating by UHF radiation:

1 - thermostat container; 2 - testing material; 3 -thermocouple; 4-foam cover; 5-measuring device

4882-74), disten-sillimanite concentrate (TU-U 14-10-01-0198), refractory aggregates (GOST 23037-78), quartz sand (GOST 2138-91), sodium chloride (GOST 13830-97);

- as environmentally and sanitary-hygienically safe binding material for model-flask and core tooling - water-closed $\beta$-gypsum (grade $\mathrm{G}-4$ ) and $\alpha$-gypsum (grade $\mathrm{G}-22$ ) that meet GOST 125-79 requirements. In this study, gypsum crumb was used. It was prepared by mechanical grinding to required fraction of water-closed gypsum of specified grades and then dried in air for 15 days at temperature of $32-35{ }^{\circ} \mathrm{C}$ and relative air humidity of $42-45 \%$.

All tested materials had been dried before investigation for 3-5 min in ultrahigh frequency furnace with nominal magnetron power of $700 \mathrm{~W}$ and then cooled in air to room temperature. Predominant tested materials grain size was $0.1-0.2 \mathrm{~mm}$.

Materials selected for testing specification and their elementary chemical compositions are given in Table 1.

Results. The experimental values of the tested material heating rate are given in Table 2.

The calculation of UHF radiation specific power, which has been used for material heating, and material relative dielectric permeability was carried out as follows.

The value of UHF radiation specific power that goes to heat any material has been calculated according to a wellknown formula [10], $\mathrm{W} / \mathrm{cm}^{3}$

$$
p=55.63 \cdot 10^{-12} \cdot \varepsilon \cdot \varepsilon_{0} \cdot E^{2} \cdot f
$$

where $\varepsilon$ is relative dielectric permeability of heated material; $\varepsilon_{0}$ is electric constant $\left(8.854 \cdot 10^{-12} \mathrm{~F} / \mathrm{m}\right) ; E$ is the electromagnetic field vector, $\mathrm{V} / \mathrm{m} ; f$ is electromagnetic field frequency, $\mathrm{Hz}$.

Duration of material heating from its initial $t_{1}$ temperature to temperature $t_{2}$ was calculated by formula, with

Granulated materials and their elementary chemical compositions

\begin{tabular}{|c|c|}
\hline Material & Elementary chemical compositions, $(\%$, weight $)$ \\
\hline Silicate-block (soda) & $\mathrm{Na}_{2} \mathrm{O} 25.4 \% ; \mathrm{SiO}_{2} 73.8 \% ; \mathrm{Al}_{2} \mathrm{O}_{3}+\mathrm{Fe}_{2} \mathrm{O}_{3} 0.47 \%$; rest $-0.33 \%$ \\
\hline Rutile & $97 \% \mathrm{TiO}_{2} ; 1.7 \% \mathrm{Fe}_{2} \mathrm{O}_{3} ; 0.5 \% \mathrm{Al}_{2} \mathrm{O}_{3} ; 0.4 \% \mathrm{SiO}_{2} ; 0.2 \% \mathrm{ZrO}_{2} ;$ rest $-0.2 \%$ \\
\hline Normal aluminum oxide & $95 \% \mathrm{Al}_{2} \mathrm{O}_{3} ; 0.5 \% \mathrm{Fe}_{2} \mathrm{O}_{3} ; 1.8 \% \mathrm{TiO}_{2} ; 0.6 \% \mathrm{CaO} ;$ rest $-2.1 \%$ \\
\hline Zircon concentrate (zirconsand) & $65 \% \mathrm{ZrO}_{2} ; 32.5 \% \mathrm{SiO}_{2} ; 2 \% \mathrm{Al}_{2} \mathrm{O}_{3} ; 0.4 \% \mathrm{TiO}_{2} ; 0.1 \% \mathrm{Fe}_{2} \mathrm{O}_{3}$ \\
\hline Disten-sillimanite concentrate & $\begin{array}{l}57.8 \% \mathrm{Al}_{2} \mathrm{O}_{3} ; 39 \% \mathrm{SiO}_{2} ; 1.8 \% \mathrm{TiO}_{2} ; 0.8 \% \mathrm{ZrO}_{2} ; 0.8 \% \mathrm{Fe}_{2} \mathrm{O}_{3} ; 0.2 \% \mathrm{MgO} ; 0.1 \% \mathrm{CaO} ; 0.1 \% \mathrm{Na}_{2} \mathrm{O}+\mathrm{K}_{2} \mathrm{O} \text {; } \\
\text { rest }-0.2 \%\end{array}$ \\
\hline Refractory aggregates & $28 \% \mathrm{Al}_{2} \mathrm{O}_{3} ; 64.5 \% \mathrm{SiO}_{2} ; 6.1 \% \mathrm{Fe}_{2} \mathrm{O}_{3} ;$ rest $-1.4 \%$ \\
\hline Quartz sand & $99.7 \% \mathrm{SiO}_{2} ; 0.07 \% \mathrm{Al}_{2} \mathrm{O}_{3} ; 0.03 \% \mathrm{Fe}_{2} \mathrm{O}_{3} ; 0.29 \%\left(\mathrm{Na}_{2} \mathrm{O}+\mathrm{K}_{2} \mathrm{O}+\mathrm{CaO}+\mathrm{MgO}\right) ;$ rest $-0.09 \%$ \\
\hline Sodium chloride & $\mathrm{NaCl} 98.2 \% ; \mathrm{H}_{2} \mathrm{O} 0.25 \%$; rest $-1.55 \%$ \\
\hline $\begin{array}{l}\beta \text {-gypsum (grade G4), } \\
\alpha \text {-gypsum (grade G22) }\end{array}$ & $\mathrm{CaSO}_{4} 98 \%$; rest $-2 \%$ \\
\hline
\end{tabular}


Table 2 materials could be calculated. Calculating results of the averHeating rate of granulated materials by UHF radiation

\begin{tabular}{|l|l|c|}
\hline \multicolumn{1}{|c|}{ Material } & \multicolumn{1}{|c|}{$\begin{array}{c}\text { Chemical formula } \\
\text { (basic substance } \\
\text { specific density, } \\
\left.\mathrm{kg} / \mathrm{m}^{3}\right)\end{array}$} & $\begin{array}{c}w, \\
{ }^{\circ} \mathrm{C} / \mathrm{min}\end{array}$ \\
\hline Silicate-block (soda) & $n \mathrm{Na}_{2} \mathrm{O} \cdot m \mathrm{miO}_{2}(2440)$ & $122.0 \pm 8$ \\
\hline Rutile & $\mathrm{TiO}_{2}(4290)$ & $38.6 \pm 1.4$ \\
\hline Normal aluminum oxide & $\alpha-\mathrm{Al}_{2} \mathrm{O}_{3}(3970)$ & $48.0 \pm 1.0$ \\
\hline Zircon concentrate & $\mathrm{ZrSiO}_{4}(4670)$ & $22.6 \pm 1.2$ \\
\hline Disten-sillimanite concentrate & $n \mathrm{Al}_{2} \mathrm{O}_{3} \cdot m \mathrm{SiO}_{2}(3520)$ & $20.4 \pm 0.8$ \\
\hline Refractory aggregates & $n \mathrm{Al}_{2} \mathrm{O}_{3} \cdot m \mathrm{SiO}_{2}(3000)$ & $25.4 \pm 2.1$ \\
\hline Quartz sand & $\mathrm{SiO}_{2}(2650)$ & $28.0 \pm 1.5$ \\
\hline Sodium chloride & $\mathrm{NaCl}^{(2164)}$ & $26.4 \pm 1.3$ \\
\hline$\beta$-gypsum (grade G4, closed) & $\mathrm{CaSO}_{4}(2320)$ & $22.6 \pm 0.9$ \\
\hline$\alpha$-gypsum (grade $\mathrm{G} 22$, closed) & $\mathrm{CaSO}_{4}(2320)$ & $12.0 \pm 0.3$ \\
\hline
\end{tabular}

$$
\tau_{\grave{A}}=\frac{c \cdot m \cdot\left(t_{2}-t_{1}\right)}{p}=\frac{c \cdot m \cdot \Delta t}{p},
$$

where $c$ is specific heat capacity of the tested (heated) material, $\mathrm{J} /\left(\mathrm{kg} \cdot{ }^{\circ} \mathrm{C}\right) ; m$ is the tested (heated) material's sample mass, $\mathrm{kg}$. Insofar as

$$
p=Z_{h} \cdot P_{M}
$$

where $Z_{h}$ is the coefficient taking into account magnetron's specific power decrease at the $i^{\text {th }}$ point of UHF furnace working space.

Then, from formula (2), it could be found that the rate of temperature rise for the heated material is, ${ }^{\circ} \mathrm{C} / \mathrm{s}$

$$
w=\frac{\Delta t}{\tau}=\frac{Z_{h} \cdot P_{M}}{c \cdot m} .
$$

At the same time, solving (2), with respect to $p$, we get

$$
p=\frac{c \cdot m \cdot \Delta t}{\tau}
$$

To carry out calculations, formula (1) could be written in form

$$
\varepsilon=\Delta \cdot p
$$

where $\Delta$ is the constant value for accepted experiment conditions, $\mathrm{cm}^{3} / \mathrm{W}$.

Using the data from Table 2, according to formulas (3) and (5), taking $\Delta=0.07 \mathrm{~cm}^{3} / \mathrm{W}$, values of $p$ and $\varepsilon$ for the studied

age values of $\varepsilon$ for the studied materials, as well as the data of $[11,12]$ are given in Table 3.

The analysis of the data in Tables 1-3 shows that among studied materials, quartz sand has the best complex of properties, including environmentally and sanitary-hygienically safety, specific density, dielectric permeability value, cost and deficit, for foundry molds and cores production using UHF heating. At the same time, it is appropriate to use $\alpha$-gypsum for model equipment and core boxes manufacturing. This choice is due to the fact that among refractory and binder materials quartz sand and $\alpha$-gypsum are characterized by one of the lowest heating rates when exposed to UHF radiation with described above parameters.

In terms of dielectric permeability, except for silicate block, the studied materials can be assigned to the group of dielectrics with low dielectric permeability $(\varepsilon<10)$. Moreover, there is direct proportional relationship between dielectric permeability and heating rate of this group of dielectric materials at $\Delta=$ $=0.07 \mathrm{~cm}^{3} / \mathrm{W}$, as evidenced by dependence plot in Fig. 2 .

Apart from the main substance, the investigated granular materials also contain substances-impurities in their composition that affect the value of their dielectric permeability. Based on the nature of tested materials occurrence, it can be stated that they are not mechanical mixtures of the main substance and substances-impurities, but alloys of these materials. Consequently, substances-impurities change not only physicochemical parameters of the main substance, but also its structure, dielectric permeability and a number of other properties and parameters.

By analogy with mechanical mixtures of dielectrics, the present work assumes existence of additive-mass influence of elemental composition of substances-impurities alloys on the dielectric permeability of the main substance. Based on this suggestion, to estimate the influence of basic substance and substances-impurities on relative dielectric permeability of the studied dielectrics with low dielectric permeability, using Table 1 and Table 3 data, the following system of equations could be written

$$
\left\{\begin{array}{l}
97 \cdot \mathrm{TiO}_{2}+1.7 \cdot \mathrm{Fe}_{2} \mathrm{O}_{3}+0.5 \cdot \mathrm{Al}_{2} \mathrm{O}_{3}+0.4 \cdot \mathrm{SiO}_{2}+0.2 \cdot \mathrm{ZrO}_{2}=6.9 \\
95 \cdot \mathrm{Al}_{2} \mathrm{O}_{3}+0.5 \cdot \mathrm{Fe}_{2} \mathrm{O}_{3}+1.8 \cdot \mathrm{TiO}_{2}+0.6 \cdot \mathrm{CaO}=7.6 \\
65 \cdot \mathrm{ZrO}_{2}+32.5 \cdot \mathrm{SiO}_{2}+2 \cdot \mathrm{Al}_{2} \mathrm{O}_{3}+0.4 \cdot \mathrm{TiO}_{2}+0.1 \cdot \mathrm{Fe}_{2} \mathrm{O}_{3}=3.2 \\
57.8 \cdot \mathrm{Al}_{2} \mathrm{O}_{3}+39 \cdot \mathrm{SiO}_{2}+1.8 \cdot \mathrm{TiO}_{2}+0.8 \cdot \mathrm{ZrO}_{2}+0.8 \cdot \mathrm{Fe}_{2} \mathrm{O}_{3}+ \\
+0.4 \cdot\left(\mathrm{Na}_{2} \mathrm{O}+\mathrm{K}_{2} \mathrm{O}+\mathrm{MgO}+\mathrm{CaO}\right)=4.3 \\
28 \cdot \mathrm{Al}_{2} \mathrm{O}_{3}+64.1 \cdot \mathrm{SiO}_{2}+6.1 \cdot \mathrm{Fe}_{2} \mathrm{O}_{3}=4.9 \\
99.7 \cdot \mathrm{SiO}_{2}+0.07 \cdot \mathrm{Al}_{2} \mathrm{O}_{3}+0.0 \cdot \mathrm{Fe}_{2} \mathrm{O}_{3}+ \\
+0.29 \cdot\left(\mathrm{Na}_{2} \mathrm{O}+\mathrm{K}_{2} \mathrm{O}+\mathrm{CaO}+\mathrm{MgO}\right)=4.6
\end{array} .\right.
$$

Table 3

Calculating results of $p$ and $\varepsilon$ for average parameter values of the studied materials heated in UHF furnaces with $2.45 \mathrm{GHz}$ frequency and nominal magnetron power of $700 \mathrm{~W}$ during $60 \mathrm{~s}$

\begin{tabular}{|l|c|c|c|c|c|c|}
\hline \multirow{2}{*}{ Material } & \multirow{2}{*}{$c, \mathrm{~J} /\left(\mathrm{kg} \cdot{ }^{\circ} \mathrm{C}\right)$} & \multirow{2}{*}{$\Delta t,{ }^{\circ} \mathrm{C}$} & \multirow{2}{*}{$m, \mathrm{~g}$} & \multirow{2}{*}{$p, \mathrm{~W} / \mathrm{cm}^{3}$} & \multicolumn{2}{c|}{$\varepsilon$} \\
\cline { 5 - 8 } & & & & & calcul. results & {$[11,12]$} \\
\hline Silicate-block (soda) & 837 & 122.0 & 144 & 245 & 17.2 & \\
\hline Rutile & 690 & 38.6 & 222 & 99 & 6.9 & $10.6-175$ \\
\hline Normal aluminum oxide & 800 & 48.0 & 170 & 109 & 7.6 & 80 \\
\hline Zircon concentrate (zircon sand) & 550 & 22.6 & 218 & 45 & 3.2 & $3.6-5.2$ \\
\hline Disten-sillimanite concentrate & 900 & 20.4 & 200 & 61 & 4.3 & \\
\hline Refractory aggregates & 825 & 25.4 & 200 & 70 & 4.9 & \\
\hline Quartz sand & 740 & 28.0 & 191 & 66 & 4.6 & $2.0-6.0$ \\
\hline Sodium chloride & 920 & 26.4 & 187 & 76 & 5.3 & \\
\hline$\beta$-gypsum (grade G4, closed) & 880 & 22.6 & 195 & 65 & 4.5 & \\
\hline$\alpha$-gypsum (grade G22, closed) & 880 & 12.0 & 195 & 34 & 2.4 & \\
\hline
\end{tabular}




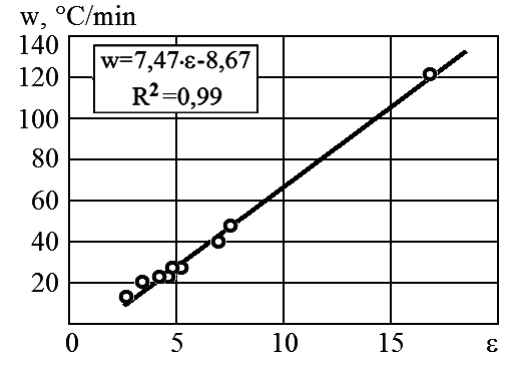

Fig. 2. Dependence $w=f(\varepsilon)$

Denoting the total mass content of $\mathrm{Na}_{2} \mathrm{O}, \mathrm{K}_{2} \mathrm{O}, \mathrm{CaO}$ and $\mathrm{MgO}$ in the analyzed materials as component $f$ and renaming it to $x_{1}, \mathrm{SiO}_{2}$ to $x_{2}, \mathrm{Al}_{2} \mathrm{O}_{3}$ to $x_{3}, \mathrm{Fe}_{2} \mathrm{O}_{3}$ to $x_{4}, \mathrm{TiO}_{2}$ to $x_{5}, \mathrm{ZrO}_{2}$ to $x_{6}$, it is possible to arrive at linear equations system of the following form

$$
\begin{aligned}
& 0.4 \cdot x_{2}+0.5 \cdot x_{3}+1.7 \cdot x_{4}+97 \cdot x_{5}+0.2 \cdot x_{6}=6.9 \\
& 0.6 \cdot x_{1}+95 \cdot x_{3}+0.5 \cdot x_{4}+1.8 \cdot x_{5}=7.6 \\
& 32.5 \cdot x_{2}+2 \cdot x_{3}+0.1 \cdot x_{4}+0.4 \cdot x_{5}+65 \cdot x_{6}=3.2 \\
& \left.39 \cdot x_{2}+57.8 \cdot x_{3}+0.4 \cdot x_{4}+1.8 \cdot x_{5}+0.8 \cdot x_{6}=4.3\right\} \text {. } \\
& 64.1 \cdot x_{2}+28 \cdot x_{3}+6.1 \cdot x_{4}=4.9 \\
& 0.29 \cdot x_{1}+99.7 \cdot x_{2}+0.07 \cdot x_{3}+0.03 \cdot x_{4}=4.6
\end{aligned}
$$

Solving equations system (6) by Gauss method, for granular inorganic materials of natural and artificial origins, containing (in weight) $\mathrm{SiO}_{2}$ in the range from 0 to $99.7 \%, \mathrm{Al}_{2} \mathrm{O}_{3}$ from 0.07 to $95.0 \%, \mathrm{ZrO}_{2}$ from 0 to $65 \%, \mathrm{TiO}_{2}$ from 0 to $97 \%, \mathrm{Fe}_{2} \mathrm{O}_{3}$ from 0.03 to $6.1 \%$ and total content of $\mathrm{Na}_{2} \mathrm{O}+$ $+\mathrm{K}_{2} \mathrm{O}+\mathrm{CaO}+\mathrm{MgO}$ from 0 to $0.6 \%$, the following equation could be obtained

$$
\begin{gathered}
\varepsilon=0.0307 \cdot \mathrm{ZrO}_{2}+0.0326 \cdot \mathrm{SiO}_{2}+0.0483 \cdot \mathrm{Al}_{2} \mathrm{O}_{3}+ \\
+0.0665 \cdot \mathrm{TiO}_{2}+0.2394 \cdot \mathrm{Fe}_{2} \mathrm{O}_{3}+4.6262 \cdot\left(\mathrm{Na}_{2} \mathrm{O}+\right. \\
\left.+\mathrm{K}_{2} \mathrm{O}+\mathrm{CaO}+\mathrm{MgO}\right),
\end{gathered}
$$

where $\mathrm{ZrO}_{2}, \mathrm{SiO}_{2}, \mathrm{Al}_{2} \mathrm{O}_{3}$ and other substances are indicated in weight $\%$.

The obtained result indicates that the relative dielectric permeability of the studied inorganic materials does not depend on their structure and, with accuracy acceptable for engineering calculations, can be determined by additive rule, based on elementary substance mass contents in their composition, by the formula (7). In addition, based on the fact that $\varepsilon=1.0001959$ for air, it is permissible for engineering calculations to use simplified formula of dependence $w=f(\varepsilon)$, which has the form

$$
W=7.47 \cdot(\varepsilon-1) .
$$

It follows from formula (8) that rate of temperature rise of material heated in a UHF radiation field is directly proportional to its relative permeability and depends only on its chemical composition.

Conclusions. It has been established that between the value of dielectric permeability and the heating rate of inorganic solid granular materials-insulators of industrial purity with predominant grain size of $0.1-0.2 \mathrm{~mm}$, heated by UHF radiation with $2.45 \mathrm{GHz}$ frequency, direct proportional relationship takes place. For dielectrics with low dielectric permeability $(\varepsilon<17)$, its value depends exclusively on their chemical composition and can be calculated according to additive rule of substances included in dielectric mass elemental composition. It was found that the heating rate of the studied material changes in the range from $12{ }^{\circ} \mathrm{C} / \mathrm{min}$ (for closed gypsum, grade G22) to $122{ }^{\circ} \mathrm{C} / \mathrm{min}$ (for silicate block). Among the studied materials for model-core equipment production, processed by UHF radiation in foundries, G22 gypsum can be recommended, for disposable foundry molds and cores manu- facturing - zircon sand, distene-sillimanite, refractory aggregates or quartz. In this case, in terms of sanitary-hygienically safety, specific density, dielectric permeability, cost and deficit for foundry molds and cores production, preference should be given to quartz sand.

\section{References.}

1. Gaponenkov, I.A., \& Fedorova, O.A. (2018). Spheres of use of the electromagnetic field of the microwave range in the modern world. Problemy regional'noy ekologii, 1, 120-126. ISSN 1728-323X.

2. Molodtsova, M.A., \& Sevastianova, Yu. V. (2017). Opportunities and prospects for the use of microwave radiation in industry (review). Lesnoy zhurnal, 2, 173-187. https://doi.org/10.17238/. 3. Gyulmaliyev, E.A., Tretiakov, V.F., \& Talyshinskiy, R. M. (2016). Chemical aspects of the development of microwave technology I. Opportunities and prospects for the use of microwave radiation. Istoriya i pedagogika yestestvoznaniya, (2), 59-68. ISSN 2226-2296.

4. Korolev, A. A., Tyurina, S. B., \& Trishkaneva, M. V. (2019). Analysis of the use of microwave radiation in sterilization technologies for plant materials. Nauchnyy zhurnal NIU ITMO. Seriya "Protsessy i apparaty pishchevykh proizvodstv", 3, 81-91. https://doi.org/10.17586/2310-1164-2019-12-3-81-91.

5. Ivanova, A.P., Barsukova, S. A., Khalimendik, A. V., \& Chumak, A. N. (2019). Analysis and prospects of research on the influence of microwave radiation on mortars and concrete. Nauka i progress transporta. Vestnik Dnepropetrovskogo natsionalnogo universiteta zheleznodorozhnogo transporta imeni akademika V. Lazaryana, 3, 121-129. ISSN 2307-3489.

6. Repyakh, S. I., \& Andreyeva, A. V. (2015). Evaluation of the uniformity of heating graphite-containing molding sand and bodies with microwave radiation. Metallurgicheskaya i gornorudnaya promyshlennost, (2), 29-32. ISSN 2076-0507.

7. Korbanov, V. D., \& Valter, A. I. (2018). Production of model equipment in foundry using additive technologies. Izvestiya Tulskogo gosudarstvennogo universiteta. Tekhnicheskiye nauki, 10, 334-338. ISSN 2071-6168.

8. Saranin, L. G. (2018). Comparative evaluation of wood materials in the manufacture of foundry equipment. Izvestiya Tulskogo gosudarstvennogo universiteta. Tekhnicheskiye nauki, 1, 16-20. ISSN 2071-6168.

9. Solonenko, L., Repyakh, S., Prokopovich, I., Sukhoi, K., \& Dmytrenko, D. (2019). System analysis of modern areas of increasing environmental and sanitary hygienic safety of using cold hardening mixtures in foundry. Pratsi Odeskoho Politekhníchnoho Universytetu, (1), 90-98. ISSN 2076-2429.

10. Komarenko, V. V., Nikichenkov, A. N., \& Molokov, V. Yu. (2017). On the use of a microwave oven for determining soil moisture. Izvestiya Tomskogo politekhnicheskogo universiteta. Inzhiniring georesursov, 11, 60-74. ISSN 2413-1830 (Scopus). 11. Pervunina, A.A. (2012). On the material composition of titanium zirconium placers of the Malyshevskyi deposit. $Z b a-$ hachennia korysnykh kopalyn: Naukovo-tekhnichnyi Zbirnyk, 50(91), 52-55. ISSN 0135-2326.

12. Schoenfeld, C., Favretto, L., \& Loechner, M. (2003). Microwave Synthesis Comes to the Academic Laboratory. American Laboratory, November.

\section{Швидкість нагріву зернистих неорганічних матеріалів надвисокочастотним випромінюванням}

\section{Л. І. Солоненко ${ }^{1}$, О. П. Білий , С. I. Реп'ях ${ }^{2}$, T. В. Кімстач ${ }^{2}$, K. I. Узлов}

1 - Одеський національний політехнічний університет, м. Одеса, Україна

2 - Національна металургійна академія України, м. Дніпро, Україна, e-mail: $\underline{123 r s @ u a . f m}$ 
Мета. Визначення швидкості нагріву зернистих матеріалів неорганічного походження, що використовуються для виготовлення ливарних форм і стрижнів, у полі надвисокочастотного випромінювання, залежності швидкості нагріву матеріалів від величини їх відносної діелектричної проникності, встановлення впливу хімічного складу та структури неорганічних матеріалів на величину їх відносної діелектричної проникності.

Методика. Дослідження проводили на наважках випробовуваних матеріалів масою 200 г, що нагрівали надвисокочастотним випромінюванням із частотою 2,45 ГГц за номінальної потужності магнетрона 700 Вт. У числі випробовуваних матеріалів: силікат-брила (содова), рутил, електрокорунд нормальний, концентрат цирконовий, концентрат дистен-силіманітовий, шамот, пісок кварцовий, натрій хлористий, $\beta$-гіпс ( $\Gamma 4$, затворений), $\alpha$-гіпс (Г22, затворений).

Результати. За результатами зміни початкової температури наважок розрахували швидкість нагріву зернистих матеріалів неорганічного походження, величини їх відносної діелектричної проникності (ع). Встановлено, що швидкість нагріву досліджених матеріалів промислової чистоти знаходиться в межах від 12 (для затвореного гіпсу марки Г22) до $122^{\circ} \mathrm{C} /$ хв (для силікатбрили).

Наукова новизна. Уперше визначені величини діелектричної проникності твердих зернистих матеріалів-діелектриків промислової чистоти з величиною $\varepsilon \leq 17$. Встановлено, що швидкість їх нагріву прямо пропорційна величині є. При цьому, величина діелектричної проникності цих матеріалів залежить виключно від їх хімічного складу й може бути розрахована за правилом адитивності елементарних хімічних компонентів, що входять до їх складу.

Практична значимість. На основі отриманих даних рекомендовані матеріали, що придатні для виготовлення ливарного модельно-стрижневого оснащення, а також ливарних формувальних і стрижневих сумішей, які працюють, що сушать або структурують під дією надвисокочастотного випромінювання. Використання таких матеріалів дозволить знизити енергоємність виробництва литих деталей і підвищити його екологічну безпеку.

Ключові слова: діелектрична проникність, надвисокочастотне випромінювання, зернистий матеріал, швидкість нагріву, ливарна форма, стрижень

\section{Скорость нагрева зернистых неорганических материалов сверхвысокочастотным излучением}

\author{
Л. И. Солоненко ${ }^{1}$ А. П. Белый ${ }^{2}$ С. И. Репях ${ }^{2}$, \\ T. В.Кимстач ${ }^{2}$ К. И. Узлов
}

1 - Одесский национальный политехнический университет, г. Одесса, Украина

2 - Национальная металлургическая академия Украины, г. Днепр, Украина, e-mail: 123rs@ua.fm

Цель. Определение скорости нагрева зернистых материалов неорганического происхождения, используемых для изготовления литейных форм и стержней, в поле сверхвысокочастотного излучения, зависимости скорости нагрева материалов от величины их относительной диэлектрической проницаемости, установление влияния химического состава и структуры нерганических материалов на величину их относительной диэлектрической проницаемости.

Методика. Исследования проводили на навесках испытуемых материалов массой 200 г, которые нагревали сверхвысокочастотным излучением с частотой 2,45 ГГц при номинальной мощности магнетрона 700 Вт. В числе испытуемых материалов: силикат-глыба (содовая), рутил, электрокорунд нормальный, концентрат цирконовый, концентрат дистен-силлиманитовый, шамот, песок кварцевый, натрий хлористый, $\beta$-гипс (Г4, затворённый), $\alpha$-гипс (Г22, затворённый).

Результаты. По результатам изменения начальной температуры навесок рассчитали скорость нагрева зернистых материалов неорганического происхождения, величины их относительной диэлектрической проницаемости $(\varepsilon)$. Установлено, что скорость нагрева исследованных материалов промышленной чистоты находится в пределах от 12 (для затворённого гипса марки Г22) до $122{ }^{\circ} \mathrm{C} /$ мин (для силикат-глыбы).

Научная новизна. Впервые определены величины диэлектрической проницаемости твёрдых зернистых материалов-диэлектриков промышленной чистоты с величиной $\varepsilon \leq 17$. Установлено, что скорость их нагрева прямо пропорциональна величине $\varepsilon$. При этом, величина диэлектрической проницаемости этих материалов зависит исключительно от их химического состава и может быть рассчитана по правилу аддитивности входящих в их состав элементарных химических компонентов.

Практическая значимость. На основе полученных данных рекомендованы материалы, пригодные для изготовления литейной модельно-стержневой оснастки, а также литейных формовочных и стержневых смесей, paботающих, высушиваемых и структурируемых в поле сверхвысокочастотного излучения. Использование таких материалов позволит снизить энергоёмкость производства литых деталей и повысить его экологическую безопасность.

Ключевые слова: диэлектрическая проницаемость, сверхвысокочастотное излучение, зернистый материал, скорость нагрева, литейная форма, стержень

Recommended for publication by V.T.Kalinin, Doctor of Technical Sciences. The manuscript was submitted 03.05.19. 